\title{
Turnitin Washback Effect: EFL Students' Methods of Avoiding Plagiarism on Academic Writing
}

\author{
Westi Haryanti Utami \\ Universitas Pendidikan Indonesia \\ westihryntami@student.upi.edu
}

\begin{abstract}
How to cite (in APA Style): Utami, W.H. (2019). Turnitin Washback Effect: EFL Students' Methods of Avoiding Plagiarism on Academic Writing. Jurnal Pendidikan Bahasa dan Sastra, 19(2), 198-210 . DOI: https://doi.org/10.17509/bs_jpbsp.v19i2.24785
\end{abstract}

Article History: Received (24 October 2018); Revised (18 March 2019); Accepted (05 Mai 2019). Journal homepage: http://ejournal.upi.edu./index.php/BS_JPBSP

\begin{abstract}
Academic dishonesty is a major issue in the current educational problem, especially in academic writing. One of the most crucial practices of academic dishonesty is plagiarism. In order to prevent it, many universities worldwide use Turnitin as one of the plagiarism detection software for the solution to fighting plagiarism. Therefore, this study aimed to identify the methods used by English as Foreign Language (EFL) students in avoiding plagiarism on their academic writing. A case study at a university in Indonesia was conducted. Six postgraduate students of English Education major were chosen as the participants to be interviewed regarding the utilization of Turnitin. From the students' responses, in avoiding plagiarism, they get the idea to write from observing their surroundings, following their passion and reading a lot. Moreover, in the process of writing academically from sources, they also employ patchwriting, citing the sources correctly, self-reading, re-checking the sources, checking to other plagiarism detection software and learning about Turnitin. However, in order to decrease the similarity percentage of their papers, they were also deleting the similar-detected part and even changed the paper. Therefore, it is recommended for the students, teachers, and institutions to concern more on how to write from sources as the part of learning to write rather than rely too much on the originality report from Turnitin.
\end{abstract}

Keywords: academic writing; EFL students; plagiarism; Turnitin

\section{Efek Washback Turnitin: Metode Mahasiswa EFL untuk Menghindari Plagiarisme pada Tulisan Akademik}

\begin{abstract}
Abstrak: Ketidakjujuran akademik adalah masalah utama dalam masalah pendidikan saat ini, terutama dalam penulisan akademik. Salah satu praktik ketidakjujuran akademik yang paling penting adalah plagiarisme. Untuk mencegahnya, banyak universitas di seluruh dunia menggunakan Turnitin sebagai salah satu perangkat lunak pendeteksi plagiarisme untuk solusi memerangi plagiarisme. Oleh karena itu, penelitian ini bertujuan untuk mengidentifikasi metode yang digunakan oleh siswa Bahasa Inggris sebagai Bahasa Asing (EFL) dalam menghindari plagiarisme pada tulisan akademik mereka. Penelitian ini merupakan studi kasus di sebuah universitas di Indonesia dilakukan. Enam mahasiswa pascasarjana Jurusan Pendidikan Bahasa Inggris dipilih sebagai peserta yang akan diwawancarai mengenai pemanfaatan Turnitin. Dari tanggapan siswa, dalam menghindari plagiarisme, mereka mendapat ide untuk menulis dari mengamati lingkungan mereka, mengikuti hasrat mereka dan banyak membaca. Selain itu, dalam proses penulisan akademis dari sumber-sumber, mereka juga menggunakan patchwriting, mengutip sumber-sumber dengan benar, membaca sendiri, memeriksa kembali sumbersumber, memeriksa ke perangkat lunak pendeteksi plagiarisme lain dan belajar tentang Turnitin. Namun, untuk mengurangi persentase kemiripan makalah mereka, mereka juga menghapus bagian yang terdeteksi serupa dan bahkan mengubah makalahnya. Oleh karena itu, disarankan bagi siswa, guru, dan lembaga untuk lebih memperhatikan cara menulis dari sumber sebagai bagian dari belajar menulis daripada mengandalkan terlalu banyak pada laporan orisinalitas dari Turnitin.
\end{abstract}

Kata kunci: penulisan akademik; Siswa EFL; plagiat; Turnitin 


\section{INTRODUCTION}

Despite the easiness and benefit that technology brings to today's education, it also has the negative effect from its utilization. The bad impact of technology is often difficult to resist and sometimes traps the users unconsciously. As one of the damaging effects from the advancement of technology in the 21st century in the educational field, academic dishonesty rates as high as 75 percent as reported by Eagle \& Hunt (2005) in Dahl (2007). The form of academic dishonesty is varied from plagiarism, cheating, fabrication, deception, bribery, sabotage, professorial misconduct, and impersonation. Particularly in higher education, plagiarism has recently in the spotlight which brings negative consequence for some universities (Kaner \& Fiedler, 2007; Goh, 2013). It closely relates to the process of maintaining academic integrity, as the essential facet in an institution, in which both staffs and students take part and work together to support and comply with it (Hamilton \& Richardson, 2008).

The product of technology development which is assumed cheering the practice of plagiarism among students in higher education is the Internet, in which much information is easily accessible across countries. There are various information and data uploaded on the Internet that can be read and downloaded freely by the students as sources or reference for their assignment. Therefore, the existence of internet is actually a challenge of honesty for those who deal with academic writing that requires enrichment from many theories and references from variety of sources. This is where the plagiarism occurs. In general, plagiarism is one's act of copying others' people work or idea and claiming it as theirs. However, the definition and types of plagiarism itself are varied and differ between cultures; non-native speakers of English and native English speakers (Graham-Matheson \& Starr, 2013; Pecorari, 2008).

Accordingly, as the technology develops very rapidly, the wisest decision according to many institutions is to counterattack the side effect of it by using the more advanced kind of technology. Turnitin, as the most used plagiarism detection software, is believed to be an effective tool dealing with plagiarism by its similarity comparison feature. There are approximately 80 countries with 10 million users who use Turnitin at the moment (Scaife in Goh, 2013). The mechanism of Turnitin is analyzing the similarity found from the paper submitted to it to the database stored digitally on the Internet and other paper on Turnitin as well (Bretag \& Carapiet, 2007; Hamilton \& Richardson, 2008). The evaluation comes out in form of similarity percentage and the link where the similarity found on the Internet. The claim on Turnitin official website, the similarity percentage does not entirely show how high plagiarism made by the students in percent, but it is more to help the teacher in the evaluation process of writing that concerns more on plagiarism.

A study conducted by Ali (2013) about the utilization of Turnitin at a university in Oman, seeking how students and teachers perceived it as a tool to minimize cyber-plagiarism. It showed that both sides responded it positively and believed that this plagiarism detection software had only a few limitations which made it an effective tool to prevent plagiarism in higher education. It was similar to Graham-Matheson \& Starr (2013) with their study that explored students and teachers at a university regarding university's policy of plagiarism and the utilization of Turnitin. The findings indicated that both students and teachers were very supportive of Turnitin since they had a clear understanding of the university's policy with Tumitin's place within it. Meanwhile, Bensal, Miraflores, \& Tan (2014) found that there were conflicting attitudes of the students 
regarding the utilization of Turnitin as plagiarism detection software at a university in Philippine. The study believed that Turnitin should be used as a feedback tool for students' writing process instead of a means to punish them based on the evaluation result. As confirmed by Dahl (2007) which examined students' attitude towards Turnitin, even though they showed a positive attitude to use this plagiarism detection software, there was a group of students who were still insecure about the correct way to quoting which made them less positive to perceive it.

Given that there is a limited study which discovers and focuses more on students' writing process that deals with plagiarism thoroughly; this study tries to fill the gap especially in Indonesia context. Hence, this study aims to inquire about students' experiences on writing an academic paper which at the same time avoiding plagiarism particularly in English as Foreign Language (henceforth, EFL) or nonnative speakers of English (henceforth, NNSEs) context. The students are postgraduate students majoring in English Education at a university in Indonesia. The focus of this study is more on how Turnitin gives effect on their approach of writing academically as the first time users of plagiarism detection software by addressing a research question; How do EFL students avoid plagiarism detected by Turnitin on their academic writing?

\section{Plagiarism}

If it is viewed through the bigger lens, plagiarism is regarded just the same by the institutions all over the world which is an act of claiming someone else's works and ideas. However, the type of plagiarism is considered differently between West and East countries or among native English speakers, students who learn English and those who use English as the medium of instruction. In the West or native English speakers (henceforth, NESs) countries, according to Graham-Matheson \& Starr (2013), plagiarism means an act of accidental, reckless or deliberate imitation or use of someone else's work for one's benefits without proper acknowledgment of the original author. The failure to cite properly can also lead the students to plagiarize other's work. Meanwhile, in eastern countries where English as Second Language (ESL) or English as Foreign Language (EFL), some identify plagiarism more carefully from students' writing process; how ones write and what purpose they hold while writing in such a way. Moreover, writing academically from sources in English for the students in those countries is considered as another sub-skill of writing itself. Therefore, plagiarism is likely to occur because they do not engage rightfully in the process of writing not because they fail to write well (Pecorari, 2008). Consequently, the terms used to define acts related to plagiarism between these different cultures are also becoming dissimilar.

Nisha, Senthil \& Bushan (2015) categorize plagiarism into five categories; accidental plagiarism, direct plagiarism, mosaic plagiarism, self-plagiarism and unintentional plagiarism. It is similar to Bakhtiyari, et al., (2014) that identify two major types of plagiarism; direct plagiarism and unconsciously plagiarism which basically cover the other four types identified by Nisha, Senthil \& Bushan (2015). Ones may fall into accidental plagiarism when they give no credit to sources used, falsifying the sources or paraphrasing a source by using homogenous words. Mosaic plagiarism concerns more on using phrases from a source without quotation or maintaining exactly the same general structure and meaning of a text with the synonyms. Moreover, when ones reusing their own previous work or combine it to their newest work without taking permission from co-authors or citing themselves, it is considered as self-plagiarism. Unintentional plagiarism is caused by accidental duplicate others' work without citation, failure in conveying their own aspiration, unaware of citing appropriately and combine others' work with theirs. 
On the other hand, in a more positive side, Pecorari (2008) believes that claiming ones are committing plagiarism need careful and thorough deliberation, especially it is closely related to learning writing as one of the aspects in language learning. Ones cannot be judged they plagiarize something since the intention to deceive is quite hard to tell. Thus, the consideration can be seen linguistically from the structure of the text which is familiar as textual plagiarism where words and/or ideas of another source are used without correct attribution. Howard (1995) claims when a text has been adapted with synonyms substitution, active verbs made passive, some words are deleted, and alteration of grammatical structures, it is entitled as patchwriting. The adaptation of a text in a new context by patchwriting shows the sign of writers' effort in the process of learning to write in which can be claimed the absent of deception itself. It is sure different from prototypical plagiarism which is purposely to deceive, for example by handling a paper written by someone else (Kennedy \& Smith, 1986; Pecorari, 2008).

Therefore, the understanding and agreement about plagiarism among students, teachers, and institution are very important. The students need to be familiar with plagiarism by learning how to write appropriately from sources not only about the linguistic feature but also concern more on how to get and use the ideas in writing. Turn out students fall into plagiarizing acts due to their lack of understanding about the plagiarism and writing from sources correctly as stated by Mahmood \& Mahmood (2014). The other study by Bretag and Carapiet (2007) also shows that $60 \%$ students in the sample fall into self-plagiarism or textual re-use of their own published papers. It was confirmed by Ahmad, Mansourizadeh \& Ai (2012), on their study which found out that nonnative postgraduate students of English in Malaysia have misconceptions about several aspects of plagiarism and cannot identify the plagiarism even though they are aware of that plagiarism is inappropriate.

Thus, plagiarism has its own space in some of academic writing books and an intriguing topic to be researched. Kennedy \& Smith (1986) on their book entitled 'Academic Writing: Working with Sources across the Curriculum', put a sub-section regarding plagiarism. The knowledge about word choice and sentence structure in writing such as paraphrasing and summarizing is essential for the students to avoid plagiarism. Moreover, the understanding of providing a proper quotation, citation, and documentation of the sources is also necessary. Bakhtiyari, et al., (2014) propose eight methods they trained to the students to avoid plagiarism in writing academically; reading from many sources, writing after few days of reading, using thesaurus/dictionary, proofreading, using machine translators, periodic selfreading, quoting and getting the idea from realistic and imaginative context.

\section{Turnitin}

Besides focusing more on the writing process, technology nowadays brings one of the solutions to help the teacher deal with plagiarism practice by plagiarism detection software. Many institutions in higher education now have taken a further step to use it since it is considered as a quick way to notice and even stop plagiarism (Ranawella \& Alagaratnam, 2017). However, it is only can be useful if it is employed in a proper way as a means to avoid plagiarism and promote honesty in educational field (Bensal, Miraflores, \& Tan, 2014). Turnitin, the most popular plagiarism detection software, has been used in more than 15 countries by now. The general mechanism of Turnitin is comparing the originality of the paper submitted to it to the database on Turnitin itself and database come from the text stored digitally on the Internet. Then, the similarity will be shown in form of percentage which shows the link of the database found similar that is called originality report. Both the students and 
the teachers have access to the originality report. The students also are given a chance to revise the paper once after knowing the result of the evaluation and then submit the revised version as well.

There are several studies that showed how Turnitin affects the plagiarism cases in higher education institutions. The first one, Bakhtiyari, et al., (2014) conducted an experimental study which trained sixteen students to use eight methods to reproduced text which have been posted online. From this study, writing after a few days of reading was the most effective method to decrease the similarity percentage. The hybrid of all methods also had significant decreasing on the similarity percentage on Turnitin. Batane (2010) with an experimental study also showed that just by knowing the paper will be submitted to Turnitin can decrease the similarity percentage of the students which means the Turnitin itself has a certain effect to some extent in students' process of writing and concern on plagiarism more. The result showed the decreasing average of similarity percentage from the first one. It implied that Turnitin can increase students' awareness in avoiding plagiarism by writing more carefully and appropriately. Moreover, Dodogovic (2014) on their action research study in which Turnitin is used to help students in paraphrasing effectively. The students at a university in China that took writing-intensive course believed that the explicit instruction after writing the drafts which were submitted to Turnitin can improve their paraphrasing skill in the writing process.

\section{METHOD}

This study was conducted under a qualitative research embracing case study as the design which is in line with the purposes of the study, exploring EFL students' method in avoiding plagiarism evaluated by Turnitin. Regarding this study, the case explored was EFL students' process of avoiding plagiarism in writing an academic paper.

\section{Site and Participants}

The participants were six postgraduate third-semester students in a state university in Bandung, Indonesia. All of the participants were English as Foreign Language learners which majoring English Education. They have attended a session and been given a handbook about plagiarism by the university at the beginning of the school year. They were also enrolled in the same course, "Research Method" and assigned to write an academic writing in form of a research proposal. The paper was then submitted on Turnitin as one of the evaluations by the lecturer.

Turnitin itself has been used in this university to check the originality of students' paper. However, the participants of this study were first time user of Turnitin which were not given any special workshop about its utilization before. They were just informed by a simple tutorial of how to create an account and how to submit their paper to Turnitin. All of the participants were informed to submit their paper on Turnitin two weeks before the submission date. Then, they got their evaluation result in form of similarity percentage and were color-coded. Then, they were given two weeks to revise their paper and were expected to get less than $24 \%$ of similarity percentage or belonged to green color. All of the participants got less than $24 \%$ of the similarity percentage as their evaluation of revised version they submitted. Hence, they were chosen based on the result of the first evaluation by Turnitin. Detailed of the participants are as follows. 
Table 1 Details of participants involved in the study

\begin{tabular}{clcccc}
\hline No. & $\begin{array}{c}\text { Name of the } \\
\text { participant } \\
\text { (pseudonym) }\end{array}$ & Gender & $\begin{array}{c}\text { Result evaluated } \\
\text { by Turnitin }\end{array}$ & $\begin{array}{c}\text { Color-coded } \\
\text { of Turnitin }\end{array}$ & Date of Interview \\
\hline 1 & Hazira & F & $24 \%$ & Green & 19 October 2017 \\
\hline 2 & Dinda & F & $46 \%$ & Yellow & 20 October 2017 \\
\hline 3 & Rina & F & $17 \%$ & Green & 20 October 2017 \\
\hline 4 & Niko & M & $28 \%$ & Yellow & 20 October 2017 \\
\hline 5 & Zam & M & $58 \%$ & Orange & 21 October 2017 \\
\hline 6 & Utari & F & $56 \%$ & Orange & 21 October 2017 \\
\hline
\end{tabular}

Thus, the reason for selecting the participants was due to the assumption that they were 'rich of information' in terms of having already known plagiarism in general, have dealt with academic writing for some time (both in undergraduate and postgraduate level), first-time user of Turnitin and were the representatives of each color evaluated by Turnitin and succeed in decrease the similarity percentage as what the lecturer expected for the revised version. Therefore they might provide useful and varied information regarding the methods used to avoid plagiarism in the process of writing an academic paper.

\section{Technique of data collection}

The data in this study were taken from two sources; interview and document. As the primary instrument to collect the data regarding methods' in avoiding plagiarism, the interview was employed to all of the participants. In regard to purposes of the study, a semi-structured interview was used to explore students' method of avoiding plagiarism in their academic writing. The process of interview was recorded by audio-recording. The secondary instrument used was the document of the evaluation result of the students' paper from Turnitin. By employing several techniques in collecting the data, it is hoped to confirm the trustworthiness of the participants.

\section{Data analysis}

As the first step in analyzing the data collected, transcribing the audio-recorded materials into the written form was done.
Then, the transcript was sent back to the interviewees to confirm its correctness with the information given. The interviewees then gave the response to the written version of data. After that, the data were coded and grouped into several themes relevant to the methods used in avoiding plagiarism. After the coding process was done, the data then simplified and compared to the literature reviews. Then, it displayed on the result and discussion section.

\section{FINDINGS AND DISCUSSION}

\section{Writing from Sources}

All of the students in this study is already familiar with academic writing and have been dealing with it for some time both in their undergraduate study and postgraduate study. The academic writings they make are a piece of writing that needs enrichment from sources or references either from theory or related studies to support their own argument. All of them are also aware of plagiarism in the process of writing and employ several similar methods in writing from sources. Therefore, below is the general theme of methods that they employ in academic writing which at the same time avoid plagiarism.

\section{Getting the idea to write}

All of the students have their own methods of getting the idea to write especially for academic writing. Some of them share exactly the same approach while some of them have their own special way. A student relates what she is going to 
write with problems she finds in the surroundings. Based on her observation of the people or things around, she admits that there are problems that bother her mind. After that, she searches related studies about it and theories that discuss the same topic:

"When I look for the idea to write, I observe my surroundings, and then some problems pop up and I begin questioning it either about the solution or the cause of that problem. From that assumption, I search the related articles about it." (Rina)

Besides that, choosing the topic based on interest or passion is also an effective way to get the idea. As the postgraduate students, some of the participants already have on their mind about their favorite topic which is something that drives their motivation to write. From this point, they start to look for another variable which they have not written yet or something which is related to current issue or trends. As noted by these students:

"I relate the experiences that I have with the topic for my writings, after I discover a problem, I connect it with my interest. For example, I'm interested in learning strategies then, I relate it to student's achievement." (Zam)

"I like to observe something related to my passion and then relate it to the current issue from my surroundings and find the significance. It's more like on exploring first which aspect that topic is still lack of, something that is rarely to be discussed and something that I think is good." (Niko)

However, some students admit that what they write is basically not always their interest or passion but from they have read before. They believe that by reading a lot can give the idea to write. On their reading process, they will stumble upon a topic in which their hearts tell them to give it a go for their writings:

"The most important way for me to get the idea for writing is by reading a lot. By reading, there are many ideas I get as an inspiration." (Dinda)

"To get the topic for my writing, I always read randomly whether it is articles or thesis, then there will be one topic that keeps bothering my mind. That's when I know I have to write about it. After that, I collect the related studies or dissertation about that topic for my reference." (Hazira) From these responses, it can be seen that the students have a positive attitude in the process of writing academically even from the way to get the idea. Those who believe that getting the idea from reading a lot is actually a good way to begin writing not only based on their passion or their observation shows that they make effort in learning to write academically. Not to be mentioned that by writing from the contemplation process in seeing the surrounding is also a good way to keep the originality of the idea. It is in line with the study by Bakhtiyari et al (2014) which propose methods for avoiding plagiarism in academic writing is by reading from many sources and getting the idea from realistic and imaginative context. They believe that from the psychological aspect, by reading from many sources, a human brain can create a concept of ideas from many sources with different wording instead of reading from one source only. Moreover, something that is earned by author's deep thinking is basically plagiarism-free.

\section{Patchwriting}

When writing from sources, most of the students have already known that adaptation is needed for their writing. The students have to use their own writing style when they use other's idea since they believe that verbatim copying is not allowed in academic writing except direct quotation and certain terms. The adaptation is called patchwriting, for example by paraphrasing, summarizing and synthesizing. It can be done by changing the synonyms of the source, changing the grammatical structure, blending similar ideas into one sentence and deleting some 
words. Most of the students in this study are paraphrasing the sources to enrich their academic writing in their own ways:

"I used to quote directly the sources for my writing, but ever since I study here I learn to paraphrase other people's ideas. So, to paraphrase it, I make a special file which consists of the collection of theories I'm going to use and paraphrase it with my own writing style by changing the passive sentence into active on and changing certain words with the synonyms." (Utari)

"I always paraphrase the theory and blend it with my own argument while I write." (Rina)

"Before paraphrasing, I collect all the sources and put it on a table on Microsoft Word so that I can synthesize the similar or the same theories into a sentence. Besides that, I change the sentence structure and change some synonyms of the words except the important term which cannot be substituted." (Zams)

"For example, when a read a sentence and want to put it into my writing, I read it more than once until I get the point and then I paraphrase it by my own style of writing which is quite different from the original one." (Dinda)

"I always make some kind of coding for the sources based on which part I want to put it for example introduction, literature review and so on into a separated file. I always paraphrase and synthesize the sources that I have collected as well. (Niko)

The adaptation of writing from sources that these students share shows their effort to not plagiarize other people's work. They see it as the process of writing academically which appreciate the experts whose theories or studies they refer to in their papers. It is in line with the study by Howard (1995) that all of the adaptation above is included as the process of learning to write which has no intention of deception. As an example of paraphrasing and synthesizing sentences by the students which are not detected as similar to anything by Turnitin is below:

\section{Learning Style}

In present education era, the learner-centered pedagogical setting becomes a crucial issue in dealing with students' approach in learning (Karthigeyan \& Nirmala, 2013). Each student is having a different way in collecting and processing information that they achieve during the learning process (Akinyode \& Khan, 2016; Nel, 2008; Ovariyanti \& Budi, 2016; Supalak, 2016; Tai, 2013).

Figure 1. Niko's academic writing

According to Haryati (2006: 15), assessment is every method teachers can use for mapping students' competence by scoring every work that they make. She also explained that assessment is about interpreting scores collected. From the explanation, it can be inferred that assessment is significant to help teachers make further decision related to students' process of learning. That is why, every curriculum like KTSP and Kurikulum 2013

Figure 2. Rina's academic writing

Citing the source correctly

Beside adaptation or modification of the sources, in academic writing, it is allowed to directly quote the source as long as the citation is correct. All scholars use citation style either from American Psychology Association (APA) and Modern Language Citation (MLA) which are the guideline of 
how to cite sources to support writing and to write the references. Some students in this study also use direct quotation when they write from sources:

"Sometimes I paraphrase the sources, but I often cite it directly and put quotation marks between the sources." (Hazira)

Apart from their choice to use direct quotation or patchwriting, all of the students agree that citation should be put adequately in their academic writings. As noted by:

"The most important thing for me is honesty, writing an appropriate citation is the way we appreciate someone else's work and effort. So, it should be well comprehended for those who deal with academic writings." (Rina)

"When we refer to other people's writings, we have to write down the reference very carefully." (Dinda)

In the writing process and citation rules, any kind of citation is allowed whether it is in form of adaptation of linguistic feature or direct quotation. These students' responses illustrate that they have adequate understanding about plagiarism and have known really well of how to write the sources and references on academic writing. As confirms by Nisha, Senthil \& Bushan (2015) who state that ones may fall into accidental plagiarism when they give no credit to sources used or falsifying the sources. Therefore, one of the best methods to avoid plagiarism is by quoting (Bakhtiyari et al, 2014). They believe that quoting someone else's words by putting the text into two quotation marks and write the reference is not considered as plagiarism.

Self-reading

After finishing their academic writing, some students check it by rereading it either right after it has finished or a few days after. They believe that sometimes there are mistakes occur which they do not notice during the writing process. Self-reading is useful for the students to point out grammar error, coherence and cohesive, and checking the citation:
"I often re-read my writings after I finish it to see whether the order of the content is correct or not. And also to check the coherence and cohesive of the content. For the grammar, sometimes I can also notice it by self-reading but I often use software to check it." (Niko)

"I wait for several days to re-reading my paper. Sometimes we cannot see the mistake right after we finish making them because we are already tired of thinking. And, yes, after three or four days, I can find the mistake that I miss and then I correct it right away." (Zams)

Furthermore, there is a student in which the method she employs for selfreading is quite different from others. She writes her paper very carefully:

"I am more like being careful in the process of writing. I re-read it in every paragraph that I write instead of finishing it first. If I find something strange in a paragraph I will modify it right away. It takes a lot of time but I enjoy it that way in writing." (Rina)

The students' responses above show that they are being really careful from the beginning while getting the idea and even after the paper is finished. Self-reading to avoid plagiarism is also in line with the study by Bakhtiyari et (2014) which state that it can make the authors notice mistakes on their own paper not only the grammatical or mistyping but also coherence and cohesiveness of the paper which can improve and increase the quality of writing.

Thus, if the effort done by the students is seen from a more positive side, judging that the students committed plagiarism just because it has the same wording or idea is not appropriate. From the students' responses regarding the way they write academic writing from sources, it can be seen that they have adequate information regarding plagiarism. Chances are the students are not actually lack of understanding about plagiarism or writing from sources but more like 'the understanding' either from the researcher or teacher is different from what the 
students believe as the part of learning to write academically. Therefore, this study is not quite in line with similar studies (Ahmad, Masourazideh \& Ai, 2012; Mahmood \& Mahmood, 2014) which show that students are lack of understanding and have misconceptions about plagiarism.

\section{Turnitin's Effect to the Writing}

Most of the students admit that as the first time users of Turnitin, they are quite panic and employ additional methods besides what they have already done, except one student whose approach to writing an academic writing is exactly the same with or without Turnitin. She shares her story:

"I am more afraid if the plagiarism is checked by the lecturer because I ever had a bad experience where I mistyped the reference and he accused me of plagiarizing something even though I did it accidentally. Since then, I am being very careful especially with the sources and the reference I use for my writing. So, Turnitin does not really give any effect because I think it is safer for me because it is done by the system, not the person." (Rina)

This student is really concerned with plagiarism because it is shown by her result of originality report which has the lowest similarity percentage in the class. Therefore she is delighted and not afraid by the utilization of Turnitin for her academic writing. Meanwhile, the other students admit they do several methods to get as low as possible similarity percentage on their originality report apart from the methods they usually do.

Learning about Turnitin

As the first time user of Turnitin, the students on this study admit that they completely have no idea about it. They do not know how it works because the lecturer informs that it will check plagiarism, which they think as misleading statement after knowing the result from Turnitin. Some of the students admit that they learn about the mechanism of Turnitin after knowing that their paper will be submitted to it:
"I also read some blogs which talk about Turnitin where many people also show their disappointment with that software." (Dinda)

"Right after I know that the paper will be submitted to Turnitin, I read the information provided on its website, about how it works and how it evaluates plagiarism. I also find articles that conduct the study about Turnitin." (Niko)

Re-checking to the sources

Most of the students re-check what they have written; whether the sources have already been paraphrased or the references have completely written and cited. As noted by these students.

"Because of Turnitin, for the first time, I re-read what I have written, especially the references. I check it thoroughly whether the people I quoted have already listed on the references." (Hazira)

"After knowing that my paper will be submitted to Turnitin, I really am frustrated of how to paraphrase the sources more carefully than before. I re-checked several times whether the sentence I write really has a different grammatical structure with the original one." (Niko)

Checking to other plagiarism detection software

Actually, there is some other free plagiarism detection software besides Turnitin. Most of the students submit their writing to it as an additional effort to check the similarity on the internet. Besides, the students admit that they use it because they do not have to pay for the feature. Some of them rely on it but some of them think the other software cannot be trusted.

"I use other plagiarism detection software which is free. In the writing process, I check paragraph by paragraph, if it is not unique according to that software, I paraphrase it again. But I guess it cannot be trusted because my similarity percentage is still high on Turnitin." (Utari)

"I ask my friends about the other plagiarism detection software that can be trusted. It is like have 10\% difference of result with Turnitin, so I use that one to check my writings." (Zams) 
"After knowing my paper will be submitted to Turnitin, I check it to other plagiarism detection software as well, and that software showed that my paper is plagiarism free. But turns out on Turnitin, I still get $24 \%$ of similarity." (Hazira)

"I also check my paper to other plagiarism detection software but the evaluation result is very different from Turnitin." (Dinda)

Deleting similar-detected parts

As the regulation by the lecturer, those who have known their similarity percentage of their paper are required to submit the revision version except those who get green-color from Turnitin evaluation. On the originality report, both the lecturer and the students can access the link in which it is found to be similar. To decrease their similarity percentage, most of the students admit that they are either re-paraphrasing or deleting the similardetected parts:

"Most of the part that is detected to be similar by Turnitin I delete. Actually, my percentage is quite low and color-coded as green so I decided to delete it rather than I re-paraphrase it." (Hazira)

"In revising the paper, besides paraphrasing the similar-detected, I also delete some of the parts I think unimportant." (Utari)

The example from the paper before and after revision from the student is:

\section{Review of Literature}

\section{Learner Motivation}

Motivation has been differently defined from various perspectives of psychology, sociology and linguistics. Some psychologists defined motivation in terms of certain needs. Brown (2001) identifies three main needs of learner motivation, that is, (1) the need for stimulation, the need to be stimulated by the environment, by other people or by ideas, thoughts

Figure 3. Utari's academic writing before revision

\section{Review of Literature}

\section{Learner Motivation}

From psychologist view, motivation has been defined in terms of certain needs. Brown (2001) identifies three main needs of learner motivation, that is, (1) stimulation, the need for stimulated by the environment, other people, other ideas, thoughts and feelings; (2)

Figure 4. Utari's academic writing after revision

Changing the paper

One of the students in this study was detected by self-plagiarism in which they have high similarity percentage on his paper which is $58 \%$. He submitted very similar paper to his other paper which is uploaded to Turnitin itself. This student then apologizes to the lecturer and asks for permission to change the paper into a completely different topic. He shares his story:

"As I said before, I write based on my passion. So, I make the same topic but with a different focus on two different subjects. Therefore, those papers share the same sources. My fault is I use quite many direct quotations which are automatically detected as similar by Turnitin. I don't put the citation from my own paper. Therefore, 
I get confused if I have to paraphrase it. So, I decide to change it to a different topic, rather than sacrificing both of the paper because both of the lecturers summon me regarding this problem." (Zams)

The effects derived from students' response that actually Turnitin gives are actually both good and bad effect on the students. The students are being extra careful in writing from sources which is good. Some of them are adding some method to avoid plagiarism in order to ensure that their paper is plagiarism free from re-checking the sources of their academic writing, learning about how Turnitin works and employing other plagiarism detection software. It makes the students being critical in writing which concerns not only to the linguistic feature and content of the paper but also how to appropriately write in an acceptable rule of citation. It is in line with the study conducted by Batane (2008) where just by knowing the paper will be submitted to Turnitin, the average similarity percentage of students originality report decreased significantly. The students may similarly employ several additional methods apart from what they already have done in writing academically just what have done by Bakhtiyari et al (2014) on their experimental study. The hybrid of all methods also can decrease the similarity percentage on Turnitin as well. However, the rule where the students have to revise their paper and get green-color as their originality paper is the one that leads the bad effect of the utilization of Turnitin. It makes the students more focus on decreasing the similarity percentage for them to delete the similar-detected part which may be a direct quotation that is not considered as plagiarism. They also become more knowledgeable since they learn about Turnitin and how it works. As the adult learners, they can criticize whether the utilization of this plagiarism detection software brings more good or not and how to react wisely to the phenomenon. As noted by Dodogovic
(2014) where the students on their action research prefer to have explicit instruction from the lecturer after submitting their paper rather than revise it by themselves.

\section{CONCLUSION}

This study revealed that postgraduate students, who have been dealing with academic writing for quite a long time, have methods that they employ to avoid plagiarism. Writing from sources is not a new thing for them. They also have an adequate understanding of plagiarism itself. Their carefulness in writing academically is not in the process of the writing only, but also from getting the idea to write and method after finishing their paper. They believe that in order to avoid plagiarism, they start getting the idea to write by observing their surroundings, writing based on their passion, and by reading a lot. As in the process of writing, they are patchwriting the sources used as enrichment for their paper such as paraphrasing, summarizing, and synthesizing. They also more concern on writing the citation appropriately. Even, after finishing the paper, they do selfreading several times to make sure the linguistic feature is correct, the content is coherence and cohesive, and the citation is not missed out.

Nonetheless, as Turnitin is used and they are required to submit their academic writing, most of them employ additional methods to avoid plagiarism such as rechecking the sources, learning about how Turnitin works and checking to other plagiarism detection software. These methods are actually good for them to be more aware of their academic writing. However, they also employ some improper ways to decrease their similarity percentage for the revision, which is deleting the similar-detected part and even changing the paper completely.

Thus, it can be concluded that Turnitin gives certain effect for the students' writing process academically in EFL context. The effect itself is both the appropriate and inappropriate ones. 
Therefore, it is strongly recommended for the institutions, teachers, and students to be more focus on the process of writing from sources, not the evaluation result of the Turnitin only. Further study on the employment of methods to write from sources with more representative participants is also recommended to be conducted.

\section{REFERENCES}

Ahmad, U., \& Mansourizadeh, K. \& Ai, G. (2012). Non-native university students' perception of plagiarism. Advances in Language and Literary Studies, 3(1), 39-48.

Ali, H. I. H. (2013). Minimizing cyberplagiarism through Turnitin: Faculty's \& students' perspectives. International Journal of Applied Linguistics \&o English Literature, 2(2), 33-42.

Bakhtiyari, K., Salehi, H., Embi, M. A., Shakiba, M., Zavvari, A., ShahbaziMoghadam, M., Ebrahim, N. A., \& Mohammadjafari, M. (2014). Ethical and unethical methods of plagiarism prevention in academic writing. International Education Studies, 7(7), 5262.

Batane, T. (2010). Turning to Turnitin to fight plagiarism among university students. Educational Technology \& Society, 13(2), 1-12.

Bensal, E. R., Miraflores, E. S., \& Tan, N. C. C. (2014). Plagiarism: Shall we turn to Turnitin? CALL-EJ, 14(2), 222.

Bretag, T., \& Carapiet, S. (2007). A preliminary study to identify the extent of self-plagiarism in Australian academic research. Plagiary: Cross-Disciplinary Studies in Plagiarism, Fabrication, and Falsification, 2(5), 1-12.

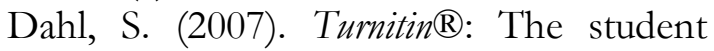
perspective on using plagiarism detection software. Active Learning in Higher Education, 8(2), 173-191.

Dodogovic, M. (2014). The role of antiplagiarism software in learning to paraphrase effectively. CALL-EJ, 14(2), 23-37.

Goh, E. (2013). Plagiarism behavior among undergraduate students in hospitality and tourism education. Journal of Teaching in Travel \& Tourism, 13(4), 307-322.

Graham-Matheson, L., \& Starr, S. (2013). Is it cheating or learning the craft of writing? Using Turnitin to help students avoid plagiarism. Research in Learning Technology, 2(1), 1-13.

Hamilton, M. \& Richardson, J. (2008). Academic integrity compliance and education. Proceedings of ASCILITE Melbourne 2008, pp.382-388.

Howard, R. M. (1995). Plagiarisms, authorships, and the academic death penalty. College English, 57, pp.788805.

Kaner, C. \& Fiedler, R. L. (2007). A cautionary note on checking software engineering papers for plagiarism. IEEE Transactions on Education, 51(2), 184-188.

Kennedy, M. L \& Smith, H. M. (1986). Academic Writing: Working with Sources across the Curriculum. New Jersey: Prentice-Hall.

Mahmood, T. \& Mahmood, A. (2014). Building a global future through research and innovative practices in open and distance learning. Turkish Online Journal of Distance Education, 15(4), 217-228.

Nisha, F., Senthil, V., \& Bushan, G. (2015). Perils of plagiarism and its cure. Proceedings of ETD 2015: 18th International Symposium on Electronic Theses and Dissertations, pp. 206-213.

Pecorari, D. (2008). Academic Writing and Plagiarism. London: Continuum.

Ranawella, T. C., \& Alagaratnam, V. (2017). Research ethics and antiplagiarism software: A study on Turnitin users of General Sir John Kotelawala Defence University (KDU). Proceedings of Information Use and User Studies, pp. 347-350. 